\title{
Effects of herbivores on a Posidonia oceanica seagrass meadow: importance of epiphytes
}

\author{
F. Tomas ${ }^{1, *}$, X. Turon ${ }^{2}$, J. Romero ${ }^{1}$ \\ ${ }^{1}$ Departament d'Ecologia and ${ }^{2}$ Departament de Biologia Animal, Invertebrats, Universitat de Barcelona, Avda. Diagonal 645, \\ Barcelona 08028, Spain
}

\begin{abstract}
There is increasing evidence that herbivory in seagrasses is more important than previously thought. However, little experimental data evaluating the importance of seagrass grazing and the factors involved in these interactions is yet available. We carried out an experimental evaluation of the effects of macroherbivores (i.e. the sea urchin Paracentrotus lividus and the sparid fish Sarpa salpa) in a temperate seagrass (Posidonia oceanica) meadow by means of 2 macroherbivore density manipulation experiments in which several measurements of plant and epiphyte vitality, and abundance were carried out. The results show that $P$. oceanica can withstand high densities of sea urchins over long periods, as no significant effect on shoot density, shoot size, leaf growth or carbohydrate reserves was detected during the time course of both experiments. Conversely, epiphyte load was significantly higher in herbivore exclusion cages; even though this increase did not appear to reduce plant vitality. Furthermore, epiphyte biomass was greatly reduced when urchins were present even at relatively low densities $\left(5\right.$ ind $\mathrm{m}^{-2}$ ), suggesting that epiphytes are the most limiting food resource for sea urchins in P. oceanica meadows. Whereas epiphyte load was only reduced $30 \%$ by the presence of fish alone, sea urchins at low densities $\left(5\right.$ ind. $\left.\mathrm{m}^{-2}\right)$ decreased epiphyte load ca. $60 \%$, reaching values as high as $80 \%$ in high density treatments, in which case the effect of fish was negligible. This study shows that in $P$. oceanica meadows, seagrass-herbivore interactions are further complicated by an underlying network of seagrass-epiphyte-herbivore, in which epiphytes appear to play a crucial role.
\end{abstract}

KEY WORDS: Herbivory · Sea urchin · Fish grazing $\cdot$ Seagrass $\cdot$ Paracentrotus lividus $\cdot$ Sarpa salpa • Benthos $\cdot$ Mediterranean

- Resale or republication not permitted without written consent of the publisher

\section{INTRODUCTION}

Although the role of herbivores seems to be modest in many seagrass meadows (Thayer et al. 1984, Nienhuis \& Groenendijk 1986, Valiela 1995), a number of studies have reported considerable effects of grazers on seagrass biomass and production (see review by Valentine \& Heck 1999) and cases of overgrazing have been repeatedly described (Camp et al. 1973, Odgen et al. 1973, Maciá \& Lirman 1999, Rose et al. 1999, Alcoverro \& Mariani 2002). Despite the increasing number of studies in this field (e.g. Verlaque 1981, Valentine \& Heck 1991, 2001, Cebrián \& Duarte 1998, Mariani \& Alcoverro 1999, Kirsch et al. 2002), the processes regulating seagrass-herbivore interactions are still poorly understood.
The low consumption rates of seagrasses by grazers generally reported have been explained by factors such as the loss of important vertebrate herbivores (e.g. green turtles, sirenians, fish and waterfowl; Thayer et al. 1984, Jackson et al. 2001) or the poor nutritional quality of the plant material (Lawrence 1975, Bjorndal 1980). Indeed, seagrasses do not appear to be an attractive food source due to their high $\mathrm{C} / \mathrm{N}$ ratios (Duarte 1990), their high content in cellulose, which most invertebrate grazers are unable to digest (Lawrence 1975), or the presence of chemical deterrents (Zapata \& McMillan 1979, McMillan et al. 1980, Agostini et al. 1998). These unappealing characteristics of seagrasses further highlight the potential role of epiphytes as an additional (or as a main) food source and suggest the existence of an interaction network in 
which epiphytes, grazers and seagrasses would be the major players. Although the role of epiphytes in seagrass herbivory has generally received little attention, in some systems, the interaction between herbivores and seagrass appears to be mediated by epiphytes, at least in part (Williams \& Heck 2001). Epiphytes have mainly been considered in studies of mesoherbivores that do not actually ingest plant material. (e.g. Orth \& van Montfrans 1984, Neckles et al. 1993, Williams \& Ruckelhaus 1993, Mukai \& Ijima 1995).

There is controversy regarding plant responses to herbivory. Whereas in some studies seagrasses suffered a herbivory-induced increase in seagrass productivity and/or shoot recruitment (e.g. Valentine et al. 1997, 2000, Maciá 2000), in others, herbivory exerted a detrimental impact on seagrass parameters (e.g. Valentine \& Heck 1991, Zimmerman et al. 1996, Rose et al. 1999, Alcoverro \& Mariani 2002). Moreover, the beneficial effect of grazers on seagrasses, by reducing competition with epiphytes for primary resources and enhancing plant production, also needs to be considered (Orth \& van Montfrans 1984, Brönmark 1985, Neckles et al. 1993, Williams \& Ruckelshaus 1993, Heck et al. 2000). In addition, nutrients seem to be able to modify all these interactions (McGlathery 1995, Heck et al. 2000, Ruiz 2000). Therefore, a full understanding of all these aspects is a major challenge for seagrass ecosystem research (Valentine \& Heck 1999).

To contribute to this end, we have carried out an experimental evaluation of the effects of herbivores in a temperate seagrass meadow. We examine the relative importance of sea urchin and fish grazing on a meadow of Posidonia oceanica, endemic to the Mediterranean. We also wanted to partially compensate the bias towards tropical and subtropical systems in the study of seagrass herbivory (see review by Valentine \& Heck 1999).

In the Mediterranean, herbivory appears to be a minor factor controlling production of the seagrass Posidonia oceanica, which is generally believed to be limited by 'bottom-up' factors such as light, temperature and nutrients (Alcoverro et al. 1995). It has been found that herbivory on $P$. oceanica accounts for only about $2 \%$ of $P$. oceanica leaf production. Most of the herbivore consumption (approximately $75 \%$ ) is due to the sparid fish Sarpa salpa (Cebrián et al. 1996). Nevertheless, the role of the common sea urchin Paracentrotus lividus is also important, and overgrazing episodes by this species have been reported (Verlaque \& Nédelec 1983, Shepherd 1987, Ruiz et al. 2001).

Under natural conditions, densities of the sea urchin Paracentrotus lividus in Posidonia oceanica meadows are generally low ( 0 to 6 ind. $\mathrm{m}^{-2}$; see review by Boudouresque \& Verlaque 2001). In these meadows, $P$. lividus preferentially feeds on the distal parts of sea- grass leaves (Ott \& Maurer 1977, Traer 1980, Verlaque \& Nédelec 1983, Nédelec \& Verlaque 1984). These leaves sustain an important epiphytic community, which can contribute up to $40 \%$ of the total biomass of P. oceanica canopies (Mazzella \& Ott 1984, Romero 1989a), and which consists mainly of crustose red algae Fosliella spp. and brown algae of the genera Myrionema, Giraudia and Cladosiphon (Ballesteros 1986, Romero 1989a). Some animals such as hydrozoans and bryozoans also appear, especially in deeper waters (Ballesteros 1986, Lepoint et al. 1999). P. lividus has been reported to feed preferentially on these epiphytes rather than on plant material (Verlaque \& Nédelec 1983, Nédelec \& Verlaque 1984, Shepherd 1987), which could be attributed to their higher nutritional quality (i.e. lower $\mathrm{C} / \mathrm{N}$ ratios) in comparison to seagrasses (Duarte 1990, Alcoverro et al. 1997, 2000).

The other main macroherbivore in Posidonia oceanica meadows, the sparid fish Sarpa salpa, also feeds on seagrass leaves and their epiphytes, and likewise, epiphytes appear to be an important part of its diet (Verlaque 1981, 1985, Velimirov 1984, Havelange et al. 1997). The pattern of herbivory is thus further complicated by possible interactions of both herbivore species.

Previous research using stable isotopes showed that Paracentrotus lividus obtains most of its nitrogen from epiphytes (Tomas 2004). Based on these results and on the known feeding preference towards old and heavily epiphytised leaves by both herbivores, the working hypothesis we put forward is that epiphytes are the key factor in the relationship between herbivores and seagrass. We test this hypothesis by assessing the changes in basic measures of vitality and abundance of both the seagrass and its epiphytes under varying degrees of grazing pressure of the 2 main herbivores present in the system. We have used a combination of density manipulations (for sea urchins) and inclusion/exclusion treatments (for fish) to examine the relative importance of sea urchin and fish grazing on Posidonia oceanica and its epiphytes in a natural, nondisturbed meadow.

\section{MATERIALS AND METHODS}

Study site. The study was carried out in a Posidonia oceanica meadow located in the Medes Islands Marine Reserve (northeast coast of Spain, northwestern Mediterranean Sea, $42^{\circ} 2^{\prime} \mathrm{N}, 3^{\circ} 13^{\prime} \mathrm{E}$ ) at a depth of 5 to $6 \mathrm{~m}$, near the upslope limit of the meadow (see Manzanera et al. 1998, Alcoverro et al. 2000 for a more detailed description). Shoot density in this meadow at this depth is between 450 and 600 shoots $\mathrm{m}^{-2}$ (Alcoverro et al. 2001). Within the depth range mentioned, 
the meadow hosts a population of adult individuals (i.e. 5 to $7 \mathrm{~cm}$ in diameter without spines) of the sea urchin Paracentrotus lividus of about 5 ind. $\mathrm{m}^{-2}$ (Romero et al. 1999, Tomas et al. 2004). The population of the herbivorous fish Sarpa salpa reaches relatively high densities, between 20 and 150 ind. $250 \mathrm{~m}^{-2}$ (Tomas 2004).

Experimental design. Two macroherbivore density manipulation experiments were carried out to examine the effects of the sea urchin Paracentrotus lividus and the sparid fish Sarpa salpa on Posidonia oceanica and its epiphytes. In the first experiment, we assessed the effect of both $P$. lividus and S. salpa, whereas in the second we evaluated the effects of the sea urchin $P$. lividus alone. In both experiments, sea urchin density was manipulated by using cages and consisted of 3 treatments: (1) sea urchin exclusion plots $\left(0\right.$ ind. $\left.\mathrm{m}^{-2}\right)$, (2) natural sea urchin density plots (approximately 5 ind. $\mathrm{m}^{-2}$ ) and (3) high sea urchin density plots (approximately 15 ind. $\mathrm{m}^{-2}$ ). These densities fall within those reported in the study area (Sala et al. 1998) and other parts of the western Mediterranean (Kempf 1962, Fenaux et al. 1987, Azzolina 1988, Palacín et al. 1998). The cages from the first experiment had no roof, so they were accessible to fish. The second experiment was conducted to evaluate the effect of sea urchins on their own and, therefore, access of the herbivorous fish $S$. salpa to the urchin-manipulated plots was impeded by adding roofs to the different cages. Three replicates per treatment (i.e. 18 cages in total) were used.

For cage deployment, plots were randomly distributed over the meadow, 3 to $5 \mathrm{~m}$ apart from each other, and treatments were randomly assigned to the plots. On each plot, a cage $1.5 \mathrm{~m} \times 1.5 \mathrm{~m}\left(2.25 \mathrm{~m}^{2}\right)$ and $0.5 \mathrm{~cm}$ high, delimited at the corners by iron bars, was installed. Fences were constructed with plastic mesh ( $2 \mathrm{~cm}$ pore size), which was attached to the seafloor with iron pegs. Roofs consisted of plastic mesh $(5 \mathrm{~cm}$ pore size) and were attached to the cage by elastic rope. At the beginning of the experiment, all sea urchins found in the cages were removed by hand and then reintroduced into the cages according to the densities assigned. When needed, additional individuals were collected from the same seagrass meadow but approximately $300 \mathrm{~m}$ away from the experimental area.

Cages can potentially introduce artefacts in the experimental results. However, we decided not to use cage controls based on previous reports demonstrating the absence of caging effects (McGlathery 1995, Maciá 2000). In any case, efforts to avoid interference were made, including periodic cleaning of roofs and walls (every $15 \mathrm{~d}$ ) to remove fouling organisms, which could reduce the light entering the cages and/or become a possible food source for urchins, and any damage was repaired as soon as detected. Sampling was carried out near the centre of the plot to avoid border effect. Light intensity inside the cages was measured using a spherical quantometer and was, on average, about 10 to $15 \%$ lower than outside. At this depth $(5 \mathrm{~m})$, this reduction is not important enough to affect plant vitality (Ruiz \& Romero 2001). However, any cage effect should be the same across sea urchin densities and should not account for differences between experimental conditions. In fact, no pernicious effect was detected in the seagrass parameters measured (see 'Results'). Furthermore, maximum epiphyte biomass was observed in the cages with roofs (see 'Results'). Epiphytes are highly sensitive to light reduction (Ruiz \& Romero 2001) and thus, if a caging effect had occurred, epiphytes would probably have been the most affected. Cages were also checked periodically to maintain the desired sea urchin densities, while drift leaves accumulating inside the cages were periodically removed to keep their abundance within natural values (Mateo \& Romero 1997).

The first experiment (i.e. fish and sea urchins) ran from June 2000 to October 2001, covering a total experimental period of $475 \mathrm{~d}$, and included 4 collection dates (June 2000, October 2000, June 2001 and October 2001, except for total carbohydrate content, which was determined in a unique sampling event, in September 2001, see below). The second experiment (i.e. sea urchins only) started in November 2000 and lasted until October 2001, covering an experimental period of $380 \mathrm{~d}$ and 3 sampling events (November 2000, June 2001 and October 2001) in addition to the collection in September 2001 for total carbohydrate analysis.

Variables measured and sampling procedures. As indicators of grazing impacts, we measured temporal changes in shoot density, leaf growth, shoot size, epiphyte biomass, bite marks and carbohydrate reserves in the rhizome of the plants within each of the cages deployed. Shoot density was estimated by placing one $0.16 \mathrm{~m}^{2}$ fixed quadrat in each of the cages, and counting all shoots within that quadrat at the beginning and at the end of the experimental period. To estimate leaf growth, the marking Zieman method modified by Romero (1989b) was used. At each sampling event, 10 shoots chosen at random were marked and harvested 3 to 4 wk later. When necessary, shoots were frozen shortly after collection and further processed in the laboratory.

In the laboratory, leaf elongation, length and width of the marked shoots were measured. Epiphytes from the collected shoots were removed by scraping with a razor blade (Alcoverro et al. 1997). Shoots and epiphytes were then dried $\left(70^{\circ} \mathrm{C}\right.$ to constant weight) and weighed separately. In June 2001 and October 2001, leaf growth rate (g dry wt [DW] shoot ${ }^{-1} \mathrm{~d}^{-1}$ ) was determined by dividing the weight of new tissue (estimated 
from the relationship between leaf area and leaf DW) by the number of days elapsed since the marking event. Epiphyte load was determined as the epiphyte biomass per shoot (g DW shoot $\left.{ }^{-1}\right)$. Shoot size was estimated as total shoot leaf biomass (g DW shoot ${ }^{-1}$ ). The frequency of leaves attacked by the 2 main herbivore species, Sarpa salpa and Paracentrotus lividus, was estimated since the bite scars left on Posidonia oceanica leaves by these herbivores are easily recognisable and of distinct shape (Boudouresque \& Meinesz 1982, Alcoverro et al. 1997).

At the end of the summer (September 2001), when maximum carbohydrate storage occurs in the rhizomes (Alcoverro et al. 2001), 3 shoots were collected haphazardly within each cage for carbohydrate reserve measurements. Rhizomes of the harvested shoots were separated and dried at $70^{\circ} \mathrm{C}$ until constant weight. The ground tissue from each of the 3 rhizomes was combined (i.e. homogenised) to determine total non-structural carbohydrates (TNC). Total carbohydrate reserve measurements were performed as described by Alcoverro et al. (2001). Sugars were solubilised from dry and ground tissues by 4 sequential extractions in $95 \%(\mathrm{v} / \mathrm{v})$ ethanol at $80^{\circ} \mathrm{C}$ for $15 \mathrm{~min}$. The ethanol extracts were evaporated under a stream of air at room temperature and the residues dissolved in deionised water for analysis. Starch was extracted from the ethanol-insoluble residue by keeping it in $1 \mathrm{~N} \mathrm{NaOH}$ for $24 \mathrm{~h}$. Sugars and starch contents of extracts were determined with a spectrophotometer using sucrose as standard, a resorcinol assay for sugar and an anthrone assay for starch.

Statistical analysis. Statistical analyses were carried out independently for each experiment, as they did not coincide in time. Hence, for each experiment, the manipulative factor to test was the sea urchin density, whereas the factor fish could only be tested indirectly through comparisons of both experiments. We used univariate methods of repeated measures ANOVA (rmANOVA, Winer et al. 1991) to assess the effects of macroherbivores on all the shoot variables measured throughout the experimental period (i.e. shoot density, shoot size, leaf growth, epiphyte load and bite marks). For each experiment, the sea urchin density treatment (exclusion, natural density and high density) was the between-subject (in our case, between-cage) factor and time (i.e. sampling events) was the repeated measures (within-cage) factor. Mean values of the shoots collected at each cage were considered as the replicates (i.e. $\mathrm{n}=3$ ).

Prior to the repeated measures ANOVA analysis, Mauchly's sphericity test is generally applied. However, following the suggestion of Quinn \& Keough (2002), it is probably safer to assume that the assumption of sphericity is not met. Therefore, corrected significance levels from Greenhouse-Geisser adjustment were used as recommended by Quinn \& Keough (2002). When a significant interaction was detected, 1-way ANOVA (Fixed Factor Sea urchin density) was carried out separately for each level of the repeated measures factor (i.e. for each sampling event) in order to conduct a posteriori pairwise comparisons of means (Student-Newman-Keuls [SNK] test, Zar 1989).

As only 1 reading of carbohydrate content was performed (in September 2001), 1-way ANOVA and ANCOVA (using shoot size as covariate) were carried out for each experiment separately to test for differences in total carbohydrate content in the rhizomes (TSC, \% DW) between treatments (fixed factor: sea urchin density). Replicates were the values obtained for each cage (i.e. $n=3$ ).

When overall significant differences were detected, a posteriori pairwise comparisons of means were performed using the SNK test.

Prior to statistical analyses, normality and homogeneity of variance were checked for all data (Kolmogorov-Smirnov Test and Cochran's test, respectively) and, when necessary, data were transformed as indicated in the 'Results' section. All differences were considered significant at $\mathrm{p}<0.05$. Analyses were performed with the STATISTICA v.4 package (StatSoft).

\section{RESULTS}

For both experiments, no significant differences among experimental conditions (i.e. sea urchin den-

Table 1. Posidonia oceanica. 1-way ANOVA/ANCOVA carried out for the 2 experiments separately to assess significant differences in total soluble carbohydrates (\% DW) in rhizomes between sea urchin density treatments. ns: not significant

\begin{tabular}{|c|c|c|c|c|c|c|c|c|c|}
\hline \multirow[t]{2}{*}{ Experiment } & \multirow[t]{2}{*}{ Effect } & \multicolumn{4}{|c|}{ ANOVA } & \multicolumn{4}{|c|}{ ANCOVA } \\
\hline & & $\mathrm{df}$ & MS & $F$ & p-value & $\mathrm{df}$ & MS & F & $\mathrm{p}$-value \\
\hline \multirow[t]{2}{*}{ Fish and urchins } & Urchin density & 2 & 14.95 & 2.142 & ns & 2 & 16.63 & 2.159 & ns \\
\hline & Error & 6 & 6.98 & & & 5 & 7.71 & & \\
\hline \multirow[t]{2}{*}{ Urchins only $^{a}$} & Urchin density & 2 & 14.19 & 1.889 & ns & 2 & 15.77 & 1.919 & ns \\
\hline & Error & 6 & 7.51 & & & 5 & 8.22 & & \\
\hline
\end{tabular}


sity) were encountered for total soluble carbohydrates, with mean values of $1.16 \pm 0.11$ (SD) \% DW for the first experiment (i.e. sea urchins and fish) and $1.24 \pm 0.07$ (SD) \% DW for the second experiment (i.e. sea urchins only, Table 1). Likewise, shoot density did not differ among experimental conditions (i.e. sea urchin density) in either of the 2 experiments and remained constant in time with values around 450 shoots $\mathrm{m}^{-2}$ (Table 2).
In both experiments, shoot size varied significantly with time, as would be expected following the seasonal growth pattern of Posidonia oceanica (Fig. 1). Neither significant differences among sea urchin densities nor a significant interaction for sea urchin $\times$ time were detected for the first experiment in shoot size (i.e. fish and urchins) (Table 2). For the second experiment (i.e. urchins only), we found a significant interaction term (sea urchin $\times$ time), explained by the fact that shoot

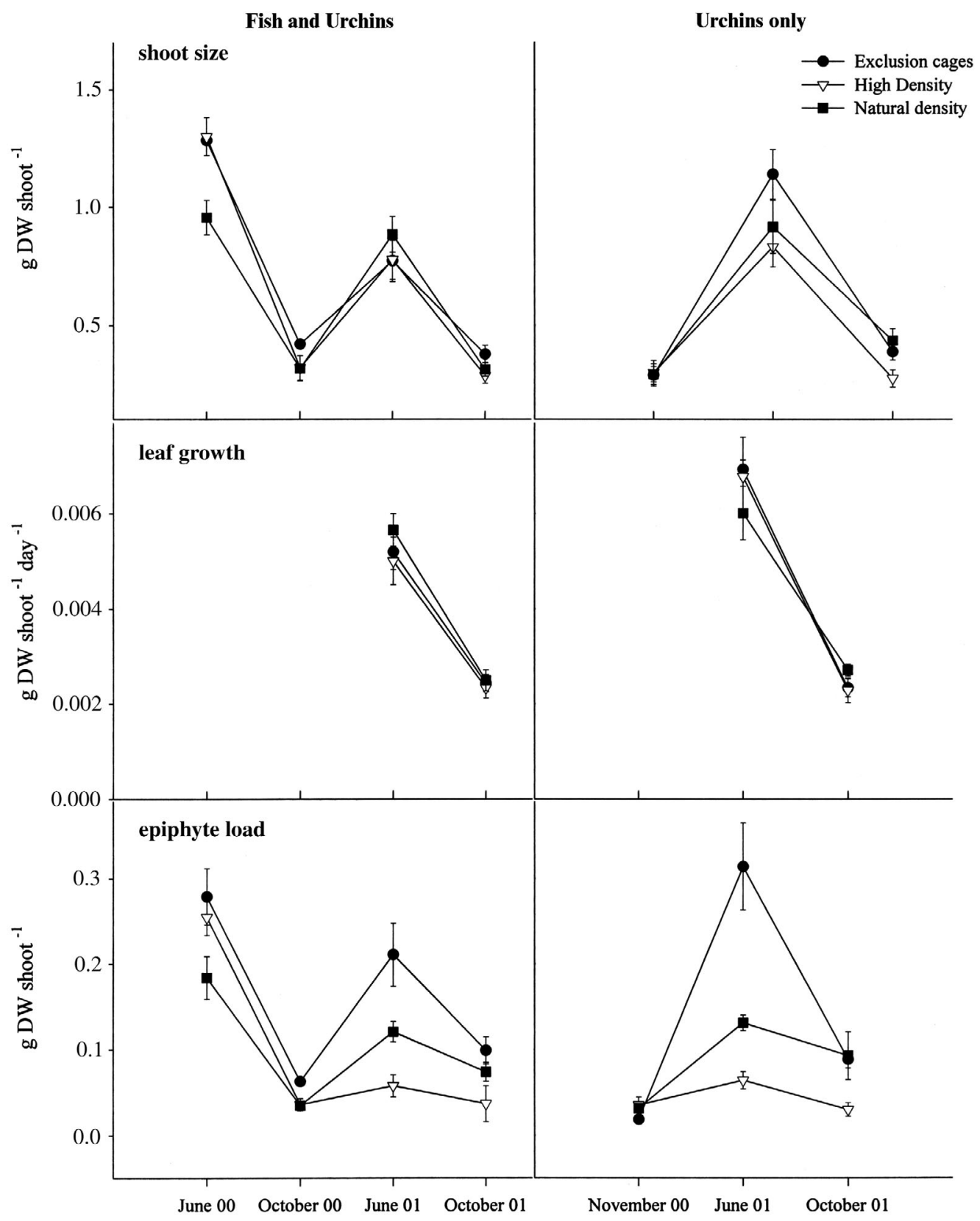

Fig. 1. Posidonia oceanica. Time course of plant and epiphyte abundance and vitality parameters (mean \pm SE) measured by shoot size, leaf growth and epiphyte load during the experimental period (2000-2001) in sea urchin exclusion plots (•), sea urchin high density plots $(\nabla)$ and sea urchin natural density plots ( $\square)$ for the 2 experiments (fish and urchins and urchins only). DW: dry weight. Bars are standard errors 
size in June 2001 was between 20 and $27 \%$ higher in the exclusion cages than in cages with urchins (Fig. 1).

Like shoot size, leaf growth also exhibited a strong seasonal pattern, being higher in June and lower in October (Fig. 1); no significant differences between sea urchin densities were detected in either of both experiments (Table 2).
Similarly, epiphyte load also experienced significant changes in time (Fig. 1) and in both experiments, we detected a significant interaction term (sea urchin density $\times$ time; Table 2). In the first experiment (i.e. sea urchins and fish), significant differences in epiphyte load among treatments started to appear in October 2000 and were very evident in June 2001, with epi-

Table 2. Posidonia oceanica. Repeated measures ANOVA performed for the 2 experiments separately to assess differences in the time course of the selected seagrass variables on cages (C) among treatments. Between-subjects sources of variation are the experimental condition (sea urchin density, U) and within-subject sources are Time $(\mathrm{T})$ and interactions. p-values correspond to those provided by the univariate $F$-test; df: degrees of freedom; MS: mean squares; ns: not significant

\begin{tabular}{|c|c|c|c|c|c|c|c|c|c|}
\hline \multirow[t]{2}{*}{ Variable } & \multirow[t]{2}{*}{ Effect } & \multicolumn{4}{|c|}{ Herbivorous fish and sea urchin } & \multicolumn{4}{|c|}{ Sea urchin only } \\
\hline & & $\mathrm{df}$ & MS & $F$ & p-value & $\mathrm{df}$ & MS & $F$ & $\mathrm{p}$-value \\
\hline \multirow[t]{7}{*}{ Shoot density } & Between-subjects & & & & & & & & \\
\hline & Sea urchin & 2 & 26.167 & 0.032 & ns & 2 & 210.39 & 0.275 & ns \\
\hline & Between-cages & 6 & 805.78 & & & 6 & 764.39 & & \\
\hline & Within-subjects & & & & & & & & \\
\hline & Time & 1 & 20.056 & 0.681 & ns & 1 & 186.89 & 2.44 & ns \\
\hline & $\mathrm{U} \times \mathrm{T}$ & 2 & 125.39 & 4.26 & ns & 2 & 22.72 & 0.297 & ns \\
\hline & $\mathrm{U} \times \mathrm{C}$ & 6 & 29.444 & & & 6 & 76.61 & & \\
\hline \multirow[t]{7}{*}{ Shoot size } & Between-subjects & & & & & & & & \\
\hline & Sea urchin & 2 & 0.028 & 2.76 & ns & 2 & 0.043 & 1.55 & ns \\
\hline & Between-cages & 6 & 0.010 & & & 6 & 0.027 & & \\
\hline & Within-subjects & & & & & & & & \\
\hline & Time & 3 & 1.500 & 144.4 & $0.000^{\mathrm{a}}$ & 2 & 1.214 & 165.6 & $0.000^{\mathrm{a}}$ \\
\hline & $\mathrm{U} \times \mathrm{T}$ & 6 & 0.038 & 3.68 & $\mathrm{~ns}^{\mathrm{a}}$ & 4 & 0.0270 & 3.68 & $0.046^{\mathrm{a}}$ \\
\hline & $\mathrm{U} \times \mathrm{C}$ & 18 & 0.010 & & & 12 & 0.0073 & & \\
\hline \multirow[t]{7}{*}{ Leaf growth } & Between-subjects & & & & & & & & \\
\hline & Sea urchin & 2 & $2.6 \mathrm{E}-7$ & 0.730 & ns & 2 & $1.07 \mathrm{E}-7$ & 0.127 & ns \\
\hline & Between-cages & 6 & $3.5 \mathrm{E}-7$ & & & 6 & $8.45 \mathrm{E}-7$ & & \\
\hline & Within-subjects & & & & & & & & \\
\hline & Time & 1 & $3.7 \mathrm{E}-5$ & 134.5 & $0.000^{\mathrm{a}}$ & 1 & $7.66 \mathrm{E}-5$ & 240.1 & $0.000^{\mathrm{a}}$ \\
\hline & $\mathrm{U} \times \mathrm{T}$ & 2 & $1 \mathrm{E}-7$ & 0.368 & ns & 2 & $7.68 \mathrm{E}-7$ & 2.407 & ns \\
\hline & $\mathrm{U} \times \mathrm{C}$ & 6 & $2.8 \mathrm{E}-7$ & & & 6 & $3.19 \mathrm{E}-7$ & & \\
\hline \multirow[t]{7}{*}{ Epiphyte load } & Between-subjects & & & & & & & & \\
\hline & Sea urchin & 2 & 0.016 & 9.64 & 0.013 & 2 & 0.0213 & 15.87 & 0.004 \\
\hline & Between-cages & 6 & 0.002 & & & 6 & 0.0013 & & \\
\hline & Within-subjects & & & & & & & & \\
\hline & Time & 3 & 0.067 & 67.10 & $0.000^{\mathrm{a}}$ & 2 & 0.0473 & 38.48 & $0.000^{\mathrm{a}}$ \\
\hline & $\mathrm{U} \times \mathrm{T}$ & 6 & 0.004 & 4.25 & $0.023^{\mathrm{a}}$ & 4 & 0.0164 & 13.29 & $0.001^{\mathrm{a}}$ \\
\hline & $\mathrm{U} \times \mathrm{C}$ & 18 & 0.001 & & & 12 & 0.0012 & & \\
\hline \multirow[t]{7}{*}{ Sea urchin bites ${ }^{b}$} & Between-subjects & & & & & & & & \\
\hline & Sea urchin & 2 & 2062.5 & 25.36 & 0.001 & 2 & 2448.0 & 15.48 & 0.004 \\
\hline & Between-cages & 6 & 81.33 & & & 6 & 158.14 & & \\
\hline & Within-subjects & & & & & & & & \\
\hline & Time & 3 & 742.07 & 9.09 & $0.017^{\mathrm{a}}$ & 2 & 1134.53 & 6.54 & $0.025^{\mathrm{a}}$ \\
\hline & $\mathrm{U} \times \mathrm{T}$ & 6 & 688.96 & 8.40 & $0.012^{\mathrm{a}}$ & 4 & 761.39 & 4.39 & $0.041^{\mathrm{a}}$ \\
\hline & $\mathrm{U} \times \mathrm{C}$ & 18 & 81.672 & & & 12 & 173.48 & & \\
\hline \multirow[t]{7}{*}{ Fish bites ${ }^{\mathrm{c}}$} & Between-subjects & & & & & & & & \\
\hline & Sea urchin & 2 & 655.03 & 4.99 & ns & 2 & 111.69 & 0.894 & ns \\
\hline & Between-cages & 6 & 131.19 & & & 6 & 124.93 & & \\
\hline & Within-subjects & & & & & & & & \\
\hline & Time & 3 & 240.06 & 1.48 & ns & 2 & 27.32 & 0.616 & ns \\
\hline & $\mathrm{U} \times \mathrm{T}$ & 6 & 454.52 & 2.80 & $\mathrm{~ns}^{\mathrm{a}}$ & 4 & 102.02 & 2.301 & ns \\
\hline & $\mathrm{U} \times \mathrm{C}$ & 18 & 162.14 & & & 12 & 44.34 & & \\
\hline
\end{tabular}


phyte load in exclusion plots being significantly higher than in plots with urchins (2-fold approximately in October 2000 and between 2- and 4 -fold in June 2001). In the second experiment (i.e. sea urchins only), differences in epiphyte load between treatments were only observed in June 2001 and, likewise, plots with no urchins presented significantly higher epiphyte load than plots in which urchins were present (between 2and 5-fold).

In short, for both experiments, epiphyte load exhibited major differences among plots with different sea urchin densities in June 2001. At this time, at high sea urchin densities, epiphyte load was low and identical in plots accessible to fish and in fish-exclusion plots (both with mean values of $0.06 \pm 0.01 \mathrm{SE} \mathrm{g} \mathrm{shoot}^{-1}$ ); similarly, under natural sea urchin densities, epiphyte load in the presence of fish (mean values $0.12 \pm 0.01 \mathrm{SE}$ $\mathrm{g}$ shoot $^{-1}$ ) was approximately the same as in their absence (mean values $0.13 \pm 0.01 \mathrm{SE} \mathrm{g} \mathrm{shoot}^{-1}$ ). Finally, in plots with no macroherbivores (no urchins and no fish), epiphyte load was approximately $30 \%$ higher (mean values $0.31 \pm 0.05 \mathrm{SE} \mathrm{g} \mathrm{shoot}{ }^{-1}$ ) than in plots where fish were the only herbivores present $(0.21 \pm$ 0.04 SE g shoot ${ }^{-1}$; Fig. 1).

In both experiments, the frequency of herbivore attacks increased in early summer, when shoot and epiphyte biomass are at their maximum (Fig. 2). This pattern was especially obvious for sea urchin bites (significant interaction term, Table 2), reaching values of approximately $60 \%$ of the leaves with marks in the high density plots, whereas in the cages with urchins, the frequency of sea urchin bites observed ranged between 0 and $20 \%$ (Fig. 2). For the first experiment (i.e. fish and sea urchins), the frequency of fish bites was relatively high and variable among treatments, although it tended to be lower in high sea urchin density plots (Fig. 2). The presence of fish bites recorded in fish exclusion cages (less than $15 \%$ in all cases) was probably due to the fact that some of the longer leaves may have partially protruded through the mesh that served as a roof, thereby becoming susceptible to attacks by fish.
Fish and Urchins

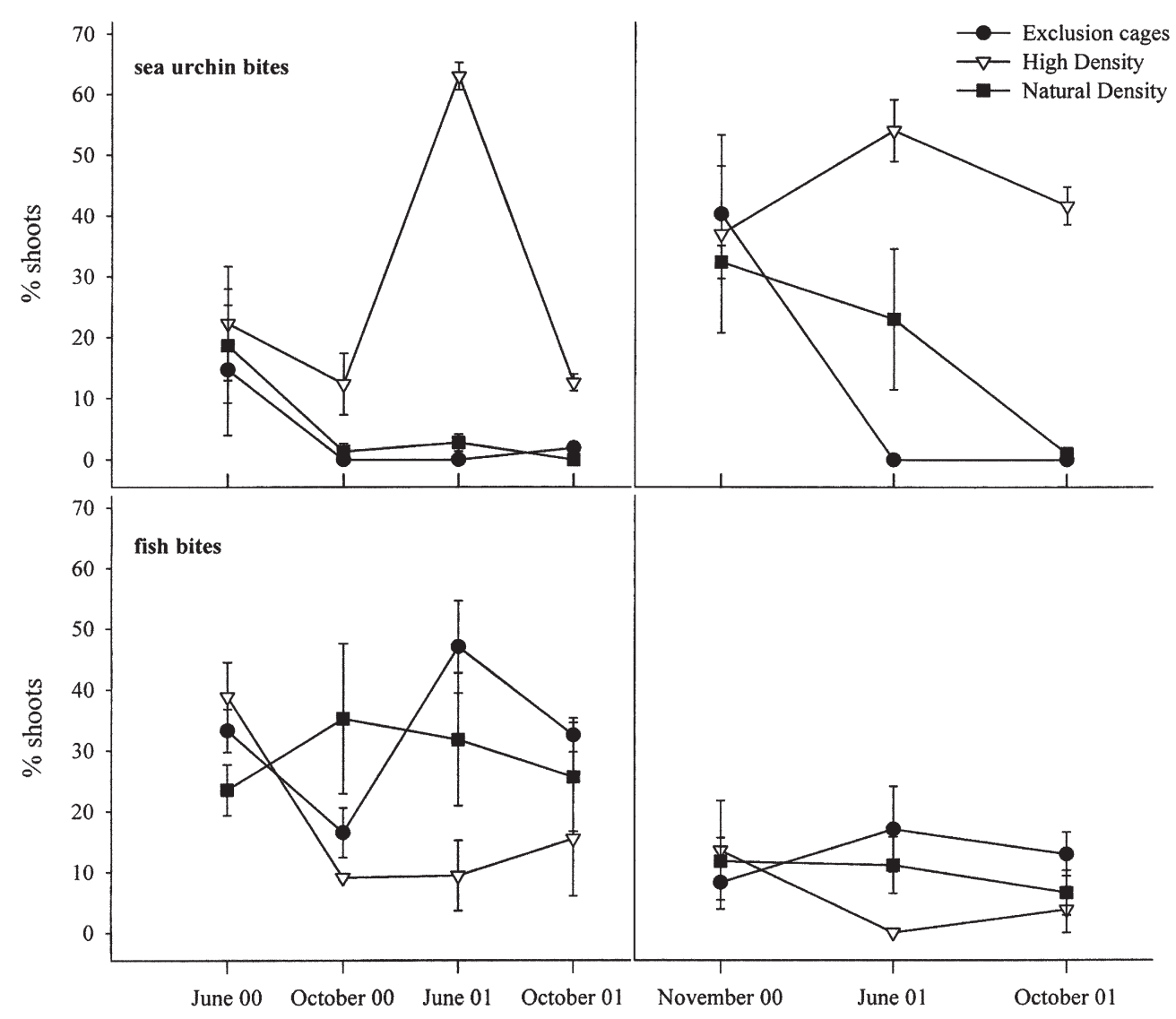

Fig. 2. Posidonia oceanica. Time course of herbivore pressure measured as percentage of shoots (mean \pm SE) with sea urchin bites and fish bites during the experimental period (2000-2001) in sea urchin exclusion plots ( $\mathbf{\square})$, sea urchin high density plots ( $\nabla)$ and sea urchin natural density plots (•) for the 2 experiments (fish and urchins, and urchins only). Bars are standard error 


\section{DISCUSSION}

Our results demonstrate that the temperate seagrass Posidonia oceanica can withstand high densities of sea urchins over long periods, at least in undisturbed environments, and that macroherbivores seem to affect the epiphytic community to a much higher degree than the plant itself.

Since no shoot mortality attributable to overgrazing was detected in any of our experimental plots, it appears that the critical sea urchin density above which the seagrass vitality could be negatively affected is clearly beyond 15 ind. $\mathrm{m}^{-2}$ (adult individuals), at least in the meadow studied. Nédelec \& Verlaque (1984) estimated a critical density at which consumption would exceed plant production and, hence, cause seagrass decline of between 25 and 50 (adult) ind. $\mathrm{m}^{-2}$ for a shallow Posidonia oceanica meadow. Nevertheless, Ruiz (2000) reported death of $P$. oceanica shoots (shoot density declined by up to 30 to $50 \%$ in $6 \mathrm{mo}$ ) in a meadow where sea urchin densities ranged between 11 to 30 ind. $\mathrm{m}^{-2}$. However, these results were obtained in an area subjected to organic loading and, although the seagrass decline seemed to be mainly caused by sea urchins (as demonstrated by a caging experiment; Ruiz 2000), it is possible that seagrass was affected by other factors associated with organic load (e.g. reduction in light, anoxia, qualitative changes in the plant and/or in the epiphytes) that would have accentuated the effects of grazing.

Sublethal effects did not appear in our experiments. Two indicators of plant vitality such as leaf growth and carbohydrate reserves (which are especially important for overwintering in this species; see Alcoverro et al. 2001) did not show any response to the increased herbivory and the only changes detected were those expected from the natural seasonal cycle of Posidonia oceanica (e.g. Alcoverro et al. 1995). All the same, other authors have reported both deleterious (e.g. Zimmerman et al. 1996, Ruiz 2000) and 'positive' grazer-induced effects in these parameters (e.g. Valentine et al. 1997, 2000, Maciá 2000). Whereas reduction of aboveground biomass is one of the most frequent outcomes of grazing (e.g. Keller 1983, Heck \& Valentine 1995, Maciá 2000, Alcoverro \& Mariani 2002), very small effects on shoot size (if any) were detected in our experiment. Only a slight increase in shoot size was observed in the plots with absence of both macroherbivores (relative to the others) during the period of maximum production (spring-summer) (Alcoverro et al. 1995).

The clearest result obtained from our experiments concerned epiphyte load, clearly higher in the exclusion cages than in the others, with those differences being more accentuated in the period of maximum epi- phyte biomass (Romero 1989a, Alcoverro et al. 1997). This higher abundance of epiphytes, allowed by the absence of herbivores, did not appear to be either detrimental or beneficial to the seagrass, as suggested by the unchanging plant vitality indicators. Certainly, grazing is often considered to have a beneficial effect on the seagrass by reducing competition with the epiphytes for primary resources (generally light), especially when an eutrophication event occurs (e.g. Orth \& van Montfrans 1984, Neckles et al. 1993, Williams \& Ruckelshaus 1993). However, in the meadow studied, epiphyte load does not appear to be sufficient to cause major impairments in the seagrass' biology, probably due to the distribution of epiphytes biased to older leaves, which are those contributing the least to the net carbon gains (Alcoverro et al. 2001).

The reported preference of both sea urchins and fish for epiphytes (e.g. Verlaque 1981, 1985, Nédelec \& Verlaque 1984, Shepherd 1987) and the results obtained in this study, suggest that epiphytes could be the most limiting food resource for grazers in Posidonia oceanica meadows. It appears that when sea urchins are present, even at low densities, they control the abundance of epiphytes. Indeed, epiphyte load was reduced ca. $60 \%$ when urchins were introduced at natural densities ( 5 ind. $\mathrm{m}^{-2}$ ). This value increased to an epiphyte load reduction of $80 \%$ when densities of urchins were high (15 ind. $\mathrm{m}^{-2}$ ). On the contrary, when Sarpa salpa was the sole herbivore present, epiphyte load was only reduced by ca. $30 \%$. Moreover, when urchins were present at high densities, reduction in epiphyte load was equivalent (i.e. ca. $80 \%$ ) in cages with or without fish, suggesting that fish were not responsible for any further decrease in epiphyte load.

Although at a large spatial scale most herbivore consumption of Posidonia oceanica seems to be carried out by the sparid fish Sarpa salpa (Cebrián et al. 1996), it is worth noting that, when present, the sea urchin Paracentrotus lividus is crucial in controlling the epiphyte community that the seagrass sustains. Nevertheless, as $S$. salpa are much more mobile than $P$. lividus (Kempf 1962, Dance 1987, Sala \& Zabala 1996) and, therefore, able to feed within a much wider area, they can probably compensate any interspecific competition for food resources by spreading their feeding area (Boudouresque \& Verlaque 2001). In fact, the spatial range and distribution of $S$. salpa can encompass thousands of square meters (e.g. Jador et al. 2002) and thus, the spatial scale of our experimental design $\left(2.25 \mathrm{~m}^{2}\right.$ cages distributed over an area of approximately $700 \mathrm{~m}^{2}$ ) was presumably insufficient to capture the spatial heterogeneity of the feeding behaviour of this species (Verlaque 1990).

The higher nutritional quality of epiphytes in comparison with the seagrass material highlights their 
importance as an essential food source. In general terms, algae are considered a better food source than seagrasses (Duarte 1995). Specifically, C/N values for epiphytes are approximately half those for Posidonia oceanica leaves (Alcoverro et al. 1997, 2000). Moreover, the findings of Tomas (2004) using stable isotope analyses indicate that approximately $90 \%$ of the nitrogen assimilated by Paracentrous lividus in the $P$. oceanica meadow studied is supplied by epiphytes. Furthermore, experimental evidence of intraspecific competition for resources among sea urchins has recently been provided (Tomas 2004), as urchins submitted to high population densities exhibited a lower reproductive potential than those at natural densities. The high consumption of epiphytes, in addition to the important assimilation of nitrogen and the evidence of intraspecific competition when sea urchin density is increased, suggest that nitrogen contained in the epiphytes is the limiting resource for sea urchins. Since the meadow studied appears to have persisted without major changes either in shoot density or in sea urchin density for the last 20 yr (Romero et al. 1999), and in the light of our results, it would seem that: (1) epiphytes are not curtailing seagrass vitality; (2) epiphyte biomass is controlled by sea urchin and fish grazing activity; (3) sea urchin grazing pressure is limited by the availability of the key resource, i.e. epiphytes; and (4) there are no major effects of grazers on the seagrass. Nevertheless, if an eutrophication event occurred, this situation could be dramatically altered (e.g. McGlathery 1995). One could expect that if total nitrogen availability for grazers increased (by increasing nitrogen content both in epiphytes and in seagrass leaves, and by increased epiphyte and shoot biomass), the food limitation on grazer population would be released, potentially causing an increase in herbivore pressure; this is exactly the case reported by Ruiz (2000) and Ruiz et al. (2001) (but see Valentine \& Heck 2001).

The results from this study open new views towards a better understanding of seagrass herbivory. Within the processes encompassed within seagrass-herbivore interactions, our work highlights the crucial function of epiphytes. Although many aspects of the processes underlying the interaction network seagrass-epiphyteherbivore still need to be resolved, it seems clear that epiphytes can play a very significant role in seagrass communities and should not be disregarded when trying to understand the factors controlling temporal and spatial variability of seagrass herbivory.

Acknowledgements. This work was supported by grant REN2002-04020-C02-02/MAR and GRC 2001 SGR 00093. The authors wish to thank M. Cáceres, O. Invers, S. LópezLegentil and P. López-Sendino for field and laboratory assistance.

\section{LITERATURE CITED}

Agostini S, Desjobert JM, Pergent G (1998) Distribution of phenolic compounds in the seagrass Posidonia oceanica. Phytochemistry 48:611-617

Alcoverro T, Mariani S (2002) Effects of sea urchin grazing on seagrass (Thalassodendron ciliatum) beds of a Kenyan lagoon. Mar Ecol Prog Ser 226:255-263

Alcoverro T, Duarte C, Romero J (1995) Annual growth dynamics of Posidonia oceanica: contribution of largescale versus local factors to seasonality. Mar Ecol Prog Ser 120:203-210

Alcoverro T, Duarte C, Romero J (1997) The influence of hervibores on Posidonia oceanica epiphytes. Aquat Bot 56: 93-104

Alcoverro T, Manzanera M, Romero J (2000) Nutrient mass balance of the seagrass Posidonia oceanica: the importance of nutrient retranslocation. Mar Ecol Prog Ser 194: $13-21$

Alcoverro T, Manzanera M, Romero J (2001) Annual metabolic carbon balance of the seagrass Posidonia oceanica (L.) Delile: the importance of carbohydrate reserves. Mar Ecol Prog Ser 211:105-116

Azzolina JF (1988) Contribution a l'étude de la dynamique des populations de l'oursin comestible Paracentrotus lividus (Lmck). Croissance, Recrutement, Mortalite, Migrations. PhD thesis, University of Aix-Marseille II, Aixen-Provence

Ballesteros E (1986) Estructura i dinàmica del poblament algal de les fulles de Posidonia oceanica (L.) Delile als herbeis de Tossa de Mar (Girona). Bull Inst Cat Hist Nat 54 (Sec Bot 6):1330

Bjorndal KA (1980) Nutrition and grazing behaviour of the green turtle Chelonia mydas. Mar Biol 56:147-154

Boudouresque CF, Meinesz A (1982) Découverte de l'herbier de Posidonies. Cah Parc National Port-Cros 4:1-81

Boudouresque CF, Verlaque M (2001) Ecology of Paracentrotus lividus. In: Lawrence JM (ed) Edible sea urchins: biology and ecology. Elsevier Science, Amsterdam, p 177-216

Brönmark C (1985) Interactions between macrophytes, epiphytes and herbivores: an experimental approach. Oikos 45:26-30

Camp D, Cobb S, Van Breedfield J (1973) Overgrazing of seagrasses by the regular urchin, Lytechinus variegatus. BioScience 23:37-38

Cebrián J, Duarte CM (1998) Patterns in leaf herbivory on seagrasses. Aquat Bot 60:67-82

Cebrián J, Duarte CM, Marbà N, Enríquez S, Gallegos M, Olesen B (1996) Herbivory on Posidonia oceanica: magnitude and variability in the Spanish Mediterranean. Mar Ecol Prog Ser 130:147-155

Dance C (1987) Patterns of activity of the sea urchin Paracentrotus lividus in the Bay of Port-Cros (Var, France, Mediterranean). PSZN I: Mar Ecol 8:131-142

Duarte CM (1990) Seagrass nutrient content. Mar Ecol Prog Ser 67:201-207

Duarte CM (1995) Submerged aquatic vegetation in relation to different nutrient regimes. Ophelia 41:87-112

Fenaux L, Etienne M, Quelart G (1987) Suivi ecologique d'un peuplement de Paracentrotus lividus (Lamarck) dans la baie de villefranche sur mer. In: Boudouresque CF (ed) Colloque International sur Paracentrotus lividus et les oursims comestibles. GIS Posidonie, Marseille, p 187-197

Havelange S, Lepoint G, Dauby P, Bouquegneau JM (1997) Feeding of the sparid fish Sarpa salpa in a seagrass ecosystem: diet and carbon flux. PSZN I: Mar Ecol 18: 289-297 
Heck KLJ, Valentine JF (1995) Sea urchin herbivory: evidence for long-lasting effects in subtropical seagrass meadows. J Exp Mar Biol Ecol 189:205-217

Heck KLJ, Pennock JR, Valentine JF, Coen LD, Sklenar SA (2000) Effects of nutrient enrichment and small predator density on seagrass ecosystems: an experimental assessment. Limnol Oceanogr 45:1041-1057

Jackson JBC, Kirby MX, Berger WH, Bjorndal KA and 10 others (2001) Historical overfishing and the recent collapse of coastal ecosystems. Science 293:629-638

Jador C, Ovidio M, Voss J (2002) Diel activity of Sarpa salpa (Sparidae) by ultrasonic telemetry in a Posidonia oceanica meadow of Corsica (Mediterranean Sea). Aquat Living Resour 150:343-350

Keller BD (1983) Coexistence of sea urchins in seagrass meadows: an experimental analysis of competition and predation. Ecology 64:1581-1598

Kempf M (1962) Recherches d'ecologie comparée sur Paracentrotus lividus (Lmk) et Arbacia lixula (L.) I. Recl Trav Stn Mar Endome 25:47-116

Kirsch KD, Valentine J, Heck KLJ (2002) Parrotfish grazing on turtlegrass Thalassia testudinum: evidence for the importance of seagrass consumption in food web dynamics of the Florida Keys National Marine Sanctuary. Mar Ecol Prog Ser 227:71-85

Lawrence J (1975) On the relationship between marine plants and sea urchins. Oceanogr Mar Biol Annu Rev 13:213-286

Lepoint G, Havelange S, Gobert S, Bouquegneau JM (1999) Fauna vs flora contribution to the leaf epiphytes biomass in a Posidonia oceanica seagrass bed (Revellata Bay, Corsica). Hydrobiologia 394:63-67

Maciá S (2000) The effects of sea urchin grazing and drift algal blooms on a subtropical seagrass bed community. J Exp Mar Biol Ecol 246:53-67

Maciá S, Lirman D (1999) Destruction of Florida Bay seagrasses by a grazing front of sea urchins. Bull Mar Sci 65: 593-601

Manzanera M, Alcoverro T, Romero J (1998) The role of the remnant leaf sheaths (scales) attached to the Posidonia oceanica (L.) Delile rhizomes. J Exp Mar Biol Ecol 223: $257-270$

Mariani S, Alcoverro T (1999) A multiple-choice feeding-preference experiment utilising seagrasses with a natural population of herbivorous fishes. Mar Ecol Prog Ser 189: 295-299

Mateo MA, Romero J (1997) Detritus dynamics in the seagrass Posidonia oceanica: elements for an ecosystem carbon and nutrient budget. Mar Ecol Prog Ser 151:45-53

Mazzella L, Ott J (1984) Seasonal changes in some features of Posidonia oceanica (L.) Delile leaves and epiphytes at different depths. In: Boudouresque CF, Grissac AJd, Olivier J (eds) International workshop on Posidonia oceanica beds. GIS Posidonie, Marseilles, p 119-127

McGlathery KJ (1995) Nutrient and grazing influences on a subtropical seagrass community. Mar Ecol Prog Ser 122: $239-252$

McMillan C, Zapata O, Escobar L (1980) Sulphated phenolic compounds in seagrasses. Aquat Bot 8:267-278

Mukai H, Ijima A (1995) Grazing effects of a gammaridean Amphipodam Amphitoe sp., on the seagrass Syringodium isoetifolium, and epiphytes in a tropical seagrass bed of Fiji. Ecol Res 10:243-257

Neckles H, Wetzel RL, Orth JR (1993) Relative effects of nutrient enrichment and grazing on epiphyte-macrophyte (Zostera marina L.) dynamics. Oecologia 93:285-295

Nédelec H, Verlaque M (1984) Alimentation de l'oursin Paracentrotus lividus (Lamarck) dans un herbier à Posidonia oceanica (L.) Delile en Corse (Mediterranée, France). In: Boudouresque CF, Jeudy de Grissac A, Olivier J (eds) International workshop on Posidonia oceanica beds. GIS Posidonie, Marseille, p 349-364

Nienhuis PH, Groenendijk AM (1986) Consumption of eelgrass (Zostera marina) by birds and invertebrates: an annual budget. Mar Ecol Prog Ser 29:29-35

Odgen JC, Brown RA, Salesky N (1973) Grazing by the echinoid Diadema antillarum Philippi: formation of halos around wet Indian patch reefs. Science 182:715-716

Orth JR, van Montfrans J (1984) Epiphyte-seagrass relationships with an emphasis on the role of micrograzing: a review. Aquat Bot 18:43-69

Ott J, Maurer L (1976) Strategies of energy transfer from marine macrophytes to consumer levels: the Posidonia oceanica example. In: Keegan BF, O' Ceidigh P, Boaden PJS (eds) Biology of benthic organisms. 11th European Symposium on Marine Biology. Pergamon Press, Oxford, p 493-502

Palacín C, Turon X, Ballesteros M, Giribert G, López S (1998) Stock evaluation of three littoral echinoid species on the Catalan coast (North-Western Mediterranean). PSZN I: Mar Ecol 19:163-177

Quinn GP, Keough MJ (2002) Experimental design and data analysis for biologists. Cambridge University Press, Cambridge

Romero J (1989a) Epífitos de las hojas de Posidonia oceanica: variaciones estacionales y batimétricasde biomasa en la pradera de las Islas Medes (Girona). Oecol Aquat 9:19-25

Romero J (1989b) Seasonal pattern of Posidonia oceanica production: growth, age and renewal of leaves. In: Boudouresque CF, Meinesz A, Fresi E, Gravez V (eds) International workshop on Posidonia beds. GIS Posidonie, Marseille, p 63-68

Romero J, Pérez M, Renom P, Invers O, Mateo MA, Tomas F, Manzanera M, dePedro X (1999) Seguimiento de la pradera de Posidonia oceanica de las Islas Medes. Ejercicio de 1999. In: Zabala M (ed) Seguiment Temporal de les Illes Medes. Departament de Medi Ambient, Generalitat de Catalunya, Barcelona

Rose CD, Sharp WC, Kenworthy WJ, Hunt JH and 6 others (1999) Overgrazing of a large seagrass bed by the sea urchin Lytechinus variegatus in Outer Florida Bay. Mar Ecol Prog Ser 190:211-222

Ruiz JM (2000) Respuesta de la fanerógama marina Posidonia oceanica (L.) Delile a perturbaciones antrópicas. PhD thesis, University of Murcia, Murcia

Ruiz JM, Romero J (2001) Effects of in situ experimental shading on the Mediterranean seagrass Posidonia oceanica. Mar Ecol Prog Ser 215:107-120

Ruiz JM, Pérez M, Romero J (2001) Effects of fish farm loading on seagrass (Posidonia oceanica). Distribution, growth and photosynthesis. Mar Pollut Bull 42:749-760

Sala E, Zabala M (1996) Fish predation and the structure of the sea urchin Paracentrotus lividus populations in the NW Mediterranean. Mar Ecol Prog Ser 140:71-81

Sala E, Ribes M, Hereu B, Zabala M, Alvà V, Coma R, Garrabou J (1998) Temporal variability in abundance of the sea urchins Paracentrotus lividus and Arbacia lixula in the northwestern Mediterranean: comparison between a marine reserve and an unprotected area. Mar Ecol Prog Ser 168:135-145

Shepherd SA (1987) Grazing by the sea urchin Paracentrotus lividus in Posidonia beds at Banyuls, France. In: Boudouresque CF (ed) Colloque International sur Paracentrotus lividus et les oursims comestibles. GIS Posidonie, Marseille, p 83-96

Thayer GW, Bjorndal KA, Odgen JC, Williams SL, Zieman JC 
(1984) Role of larger herbivores in seagrass communities. Estuaries 7:351-376

Tomas F (2004) Herbivory in seagrass ecosystems: population dynamics and trophic relations in a Posidonia oceanica (L.) Delile meadow. PhD thesis, University of Barcelona, Barcelona

Tomas F, Romero J, Turon X (2004) Settlement and recruitment of the sea urchin Paracentrotus lividus in two contrasting habitats in the Mediterranean. Mar Ecol Prog Ser 282:173-184

Traer K (1980) The consumption of Posidonia oceanica Delile by echinoids at the isle of Ischia. In: Jangoux M (ed) European Colloquium Echinoderms 'Echinoderms: Present and Past'. Balkema, Rotterdam, p 241-242

Valentine J, Heck KLJ (1991) The role of sea urchin grazing in regulating subtropical seagrass meadows: evidence from field manipulations in the northen Gulf of Mexico. J Exp Mar Biol Ecol 154:215-230

Valentine JF, Heck KLJ (1999) Seagrass herbivory: evidence for the continued grazing of marine grasses. Mar Ecol Prog Ser 176:291-302

Valentine J, Heck KLJ (2001) The role of leaf nitrogen content in determining turtlegrass (Thalassia testudinum) grazing by a generalized herbivore in the northeastern Gulf of Mexico. J Exp Mar Biol Ecol 258:65-86

Valentine JF, Heck KLJ, Busby J, Webb D (1997) Experimental evidence that herbivory increases shoot density and productivity in a subtropical turtlegrass (Thalassia testudinum) meadow. Oecologia 112:193-200

Valentine JF, Heck KLJ, Kirsch KD, Webb D (2000) Role of sea urchin Lytechinus variegatus grazing in regulating subtropical turtlegrass Thalassia testudinum meadows in the Florida Keys (USA). Mar Ecol Prog Ser 200:213-228

Valiela I (1995) Marine ecological processes. Springer-Verlag, New York

Editorial responsibility: Otto Kinne (Editor-in-Chief), Oldendorf/Luhe, Germany
Velimirov B (1984) Grazing of Salpa salpa L. on Posidonia oceanica and utilization of soluble compounds. In: Boudouresque CF, Jeudy de Grissac A, Olivier J (eds) International workshop on Posidonia oceanica beds. GIS Posidonie, Marseille, p 381-387

Verlaque M (1981) Preliminary data on some Posidonia feeders. Rapp Comm Int Mer Médit 27:201-202

Verlaque M (1985) Note preliminaire sur le comportement alimentaire de Sarpa salpa (L.) (Sparidae) en Mediterranée. Rapp Comm Int Mer Médit 29(5):193-196

Verlaque M (1990) Relations entre Sarpa salpa (Linnaeus, 1758) (Téléostéen, Sparidae), les autres poissons broteurs et le phytobenthos algal méditerranéen. Oceanol Acta 13:373-388

Verlaque M, Nédelec H (1983) Note préliminaire sur les relations biotiques Paracentrotus lividus (LMK.) et herbier de Posidonies. Rapp Comm Int Mer Médit 28: $157-158$

Williams SL, Heck KLJ (2001) Seagrass community ecology. In: Bertness MD, Gaines SD, Hay ME (eds) Marine community ecology. Sinauer Associates, Sunderland, MA, p 317-337

Williams SL, Ruckelhaus MH (1993) Effects on nitrogen availability and herbivory on eelgrass (Zostera marina) and epiphytes. Ecology 74(3):904-918

Winer BJ, Brown DR, Michels KM (1991) Statistical principles in experimental design. McGraw-Hill, New York

Zapata O, McMillan C (1979) Phenolic acids in seagrasses. Aquat Bot 7:307-317

Zar JH (1989) Biostatistical analysis. Prentice-Hall, Englewood Cliffs, NJ

Zimmerman R, Kohrs D, Alberte R (1996) Top-down impact through a bottom-up mechanism: the effect of limpet grazing on growth, productivity and carbon allocation of Zostera marina L. (eelgrass). Oecologia 107:560-567

Submitted: December 18, 2003; Accepted: August 3, 2004

Proofs received from author(s): February 9, 2005 